\title{
STRATEGI SWITCHING PREMI DALAM PENGUMPULAN DANA MASYARAKAT SEKTOR INFORMAL SEBAGAI UPAYA PENCEGAHAN KETERLAMBATAN PEMBAYARAN PREMI JAMINAN KESEHATAN NASIONAL
}

\section{PREMIUM SWITCHING STRATEGY ON REVENUE COLLECTION FROM INFORMAL SECTOR COMMUNITY : EFFORT TO PREVENT PREMIUM PAYMENT DELAY ON JKN}

\author{
Arih Diyaning Intiasari ${ }^{1}$ Laksono Trisnantoro $^{2}$ Julita Hendrartini $^{2}$ \\ ${ }^{1}$ Universitas Jenderal Soedirman Purwokerto \\ ${ }^{2}$ Prodi S2 Ilmu Kesehatan Masyarakat Fakultas Kedokteran Universitas Gadjah Mada
}

\begin{abstract}
ABSTRAK
Kenaikan defisit anggaran BPJS dalam 3 tahun pertama pelaksanaan JKN memerlukan perhatian khusus. Salah satu masalah dalam penerapan JKN adalah tingginya keterlambatan pembayaran premi oleh peserta Non PBI Mandiri. Tujuan dari penelitian ini adalah untuk mengetahui persepsi peserta Non PBI Mandiri terhadap rekomendasi strategi transisi JKN premium payer. Penelitian ini merupakan kebijakan dengan pendekatan deskriptif kualitatif. Desain penelitian yang digunakan kebijakan yang bertujuan untuk menyusun rekomendasi adalah Studi Kasus mengenai fenomena keterlambatan pembayaran premi. Kedalaman wawancara dengan 11 informan peserta Independen Non PBI dilakukan dengan sistem kuota purposive sampling. Hasil penelitian menunjukkan bahwa adanya konsekuensi positif sebagai respon masyarakat terhadap konsep strategi pembayar premi transisional. Peserta mengaku sangat terbantu jika program ini digelar karena bisa meringankan beban biaya pengobatan mereka saat usianya sudah lanjut dan tidak memiliki penghasilan lagi, memberikan ketenangan dalam kepastian perubahan premi asuransi di usia tidak produktif. Kesimpulan dari penelitian ini adalah terobosan yang dilakukan dalam strategi pembayar premi transisi telah mendapat tanggapan positif dari tujuan kebijakan publik

Keywords: Strategy shift premium payer, Non PBI Mandiri, informal sector
\end{abstract}

\section{ABSTRACT}

The increase in the budget deficit BPJS in the first 3 years of implementation JKN require special attention. One of the problems in the implementation of JKN is high late payment of premiums by the participants of the Non PBI Mandiri.The purpose of this study was to determine the participants' perceptions of Non PBI Mandiri to the recommendations transition strategy JKN premium payer. This study is a policy with qualitative descriptive approach. The study design used policy aims to draw up a recommendation is the Case Study on the phenomenon of late payment of premiums. Depth interviews with 11 informants participants Independent Non PBI done with purposive sampling quota system. The result showed that the presence of positive consequences as the public response to the concept of a transitional strategy premium payer. Participants claimed to be greatly assisted if the program was held because it can ease the burden of their medical expenses when his advanced age and does not have income again, providing peace in the certainty of change of insurer premiums in non-productive age. Conclusion of the study were breakthrough made in a transitional strategy premium payer has received positive responses from the public policy goals.

Keywords: Strategy shift premium payer, Non PBI Mandiri, informal sector

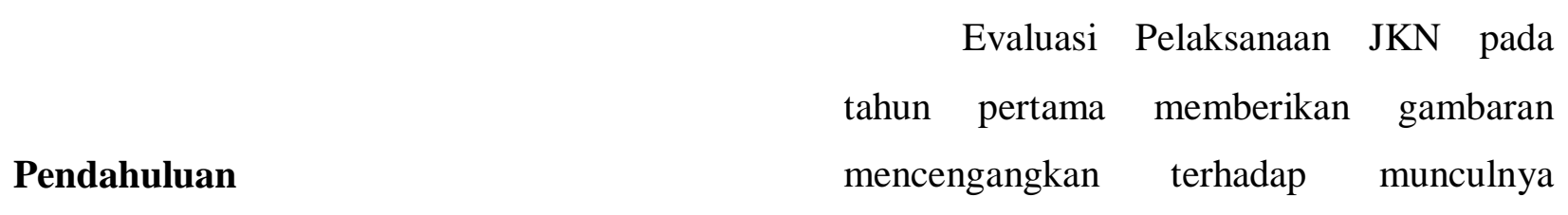


fenomena adverse selection pada skema Peserta Non PBI Mandiri. Tingginya konsentrasi jumlah Peserta Non PBI Mandiri yang mendaftar dengan resiko tinggi untuk memanfaatkan pelayanan kesehatan dalam jangka pendek menimbulkan tingginya besaran rasio klaim pelayanan kesehatan. Idealnya, tidak akan terjadi fenomena adverse selection dalam sebuah skema asuransi kesehatan sosial. Hal tersebut akan tercapai apabila skema asuransi dapat memenuhi prinsip the law of the large number melalui serangkaian kebijakan.

Berbagai kebijakan yang muncul untuk mengendalikan adverse selection saat ini adalah dengan menetapkan aturan waktu tunggu penggunaan pelayanan kesehatan. Kebijakan pada level mikro berupa Peraturan BPJS Kesehatan No 4 Tahun 2014 tentang Tata Cara Pendaftaran dan Pembayaran Peserta Perorangan telah direvisi dengan Peraturan BPJS Kesehatan No 1 Tahun 2015 dengan Peraturan Direksi BPJS Kesehatan No 32 Tahun 2015 Tentang Petunjuk Teknis Tata Cara Pendaftaran dan Pembayaran Iuran bagi Peserta Pekerja Bukan Penerima Upah dan Peserta Bukan

Pekerja. Peraturan Direksi BPJS Kesehatan No.32 Tahun 2015 yang telah ditetapkan pada 1 Juli 2015 tersebut masih mengatur secara implisit adanya waktu tunggu penggunan manfaat pelayanan kesehatan bagi Peserta Non PBI Mandiri. Yaitu dengan penetapan pasal yang mengatur bahwa pemberian manfaat jaminan pelayanan kesehatan dapat diberikan setelah peserta membayar premi pertamanya. Adapun pembayaran premi pertama hanya bisa dilakukan paling cepat adalah 14 hari setelah virtual Account (VA) dikeluarkan oleh BPJS Kesehatan. Kendati peraturan tersebut mempunyai konsekuensi positif akan tetapi tetap diperlukan terobosan kebijakan guna meningkatkan partisipasi masyarakat sektor informal dalam kepesertaan JKN. Aktivasi tombol kebijakan pada aspek pooling juga harus diimbangi dengan aktivasi penggerakan revenue collection pada mekanisme kepesertaan masyarakat sektor informal. Strategi switching premi adalah salah satu pemikiran untuk memperluas cakupan kepesertaan JKN dan memperkecil kemungkinan keterlambatan pembayaran premi. Rekomendasi kebijakan ini diharapkan dapat digunakan sebagai masukan dalam law enforcement policy dalam pelaksanaan JKN. Oleh karena itu perlu dilakukan studi untuk mengetahui persepsi stakeholder terhadap rekomendasi ini. 


\section{METODE PENELITIAN}

Penelitian ini merupakan penelitian kebijakan dengan pendekatan deskriptif kualitatif. Desain penelitian kebijakan yang digunakan bertujuan untuk menyusun sebuah rekomendasi adalah Studi Kasus pada fenomena keterlambatan pembayaran premi selama minimal 6 bulan pada $55 \%$ Peserta Non PBI Mandiri yang terdaftar pada wilayah Kantor Perwakilan Cabang BPJS Kesehatan Kabupaten Banyumas. Tujuan dari penelitian ini adalah untuk menyusun rekomendasi kebijakan berbasis riset dan kearifan lokal dalam upaya pengumpulan premi pada masyarakat sektor informal dan mengetahui persepsi peserta Non PBI Mandiri terhadap rekomenadasi yang diusulkan.

Sintesis terfokus telah dilakukan dalam menyusun rekomendasi switching premi . Wawancara mendalam terhadap 11 informan dengan sistem quota prurposif dilakukan untuk menjamin keterwakilan masyarakat sektor informal di rural maupun urban di wilayah Kabupaten Banyumas agar terwakili sebagai informan penelitian.

\section{HASIL DAN PEMBAHASAN}

Upaya untuk meningkatkan partisipasi kepesertaan JKN dan mencegah keterlambatan premi merupakan usaha untuk mengatasi fenomena self selection dalam skema non PBI Mandiri saat ini. Pengenalan pada konten masalah dan karakteristik sasaran kebijakan harus dilakukan untuk memberikan solusi yang tepat guna.

Sudah tepatkah kebijakan pencegahan self selection saat ini? Strategi pencegahan self selection diatur melalui Peraturan BPJS Kesehatan No 1 Tahun 2015 dengan Peraturan Direksi BPJS Kesehatan No 32 Tahun 2015 Tentang Petunjuk Teknis Tata Cara Pendaftaran dan Pembayaran Iuran bagi Peserta Pekerja Bukan Penerima Upah dan Peserta Bukan Pekerja. Kebijakan yang mengedapankan aturan waktu tunggu pelayanan ini terbukti bukan merupakan kebijakan populer dari JKN. Kebijakan ini justru menuai banyak protes dari masyarakat akibat tertundanya manfaat jaminan pembiayaan pelayanan kesehatan.

Siapa sebenarnya masyarakat sektor informal peserta Non PBI Mandiri? Identifikasi menyeluruh terhadap karakteristik dan kebutuhan pelayanan kesehatan pada masyarakat sektor informal harus dilakukan dengan baik. Beberapa yang perlu mendapat perhatian dari pengambil kebijakan adalah hal hal sebagai berikut :

1. Mayoritas masyarakat sektor informal adalah Petani di Perdesaan Sebagian besar responden tinggal di wilayah 
perdesaan $(62,7 \%)$ dan sebanyak $46,3 \%$ responden bermata pencaharian sebagai petani.

2. Status Ekonomi Walaupun responden merupakan masyarakat yg mayoritas mempunyai status ekonomi dengan 3 quintile terbawah (Q1 24,3\%, Q2 22,3\%, Q3 21,1\%) namun 87,8 \% nya mempunyai status pemukiman milik sendiri. Mayoritas masyarakat sektor informal sebenarnya mempunyai potensi untuk membayar premi pada jaminan kesehatan nasional.

3. Kelompok Umur Lansia Membutuhkan Jaminan Kesehatan Pada responden yang mayoritas berusia produktif 26-55 tahun $(69,9 \%)$ didapatkan bahwa $99 \%$ mereka tidak atau belum pernah mengalami riwayat penyakit kronis.Masyarakat sektor informal adalah masyarakat yang relatif sehat dalam kurun usia produktifnya. Hasil penelitian menunjukkan semakin tinggi usia responden pada sektor informal maka semakin besar kemungkinannya untuk tidak memiliki jaminan kesehatan. Adanya fenomena peningkatan kemungkinan kepemilikan jaminan kesehatan pada kategori umur 46-55 tahun menunjukkan bahwa pada usia tersebut responden merasakan adanya kebutuhan terhadap perlindungan pembiayaan kesehatan yang sebelumnya tidak mereka butuhkan. Kelompok inilah yang diprediksi merupakan populasi yang berkontribusi pada fenomena adverse selection dalam JKN di Indonesia.

Ada kecenderungan masyarakat sektor informal untuk mempunyai jaminan kesehatan pada usia lanjut. Yaitu usia dimana masalah kesehatan degeneratif mulai bermunculan. Sementara pada usia produktif mereka merasa tidak memerlukan jaminan kesehatan, hal ini karena mayoritas mereka tidak pernah mengalami gejala atau gangguan penyakit yang kronis.

Kebutuhan pelayanan kesehatan tersebut tidak lagi Ada kecenderungan masyarakat sektor informal untuk mempunyai jaminan kesehatan pada usia lanjut. Yaitu usia dimana masalah kesehatan degeneratif mulai bermunculan. Sementara pada usia produktif mereka merasa tidak memerlukan jaminan kesehatan, hal ini karena mayoritas mereka tidak pernah mengalami gejala atau gangguan penyakit yang kronis. diimbangi dengan kemampuan masyarakat sektor informal untuk menghasilkan pendapatan seperti ketika mereka masih berusia produktif. Pada usia lanjut tidak lagi ada kepastian akan 
kesanggupan mereka membayar premi asuransi kesehatan secara berkesinambungan Formulasi kebijakan pembiayaan kesehatan seharusnya mampu mewujudkan sistem yang dapat negara. menjembatani kelompok sektor informal usia lanjut ini. Pemenuhan kebutuhan kesehatan pada kelompok masyarakat usia lanjut harusnya merupakan tanggung jawab

\section{Pergeseran Kebutuhan Jaminan Kesehatan}

\begin{tabular}{|c|c|}
\hline $\begin{array}{c}\text { Sektor Informal Usia } \\
\text { Produktif (26-54 th) }\end{array}$ & $\begin{array}{c}\text { Sektor informal Usia } \\
\text { Non produktif (55-65) }\end{array}$ \\
\hline $\begin{array}{c}\text { 99\% pekerja sektor } \\
\text { informal belum } \\
\text { pernah mengalami } \\
\text { gangguan penyakit } \\
\text { kronis }\end{array}$ & $\begin{array}{c}\text { Ada kemungkinan 8 kali } \\
\text { lebih besar untuk } \\
\text { masyarakat sektor } \\
\text { informal untuk mengikuti } \\
\text { asuransi kesehatan }\end{array}$ \\
\hline
\end{tabular}

Gambar 1. Pergeseran Kebutuhan Jaminan Kesehatan Masyarakat Sektor Informal Sumber :Intiasari, dkk, 2014

Fenomena tingginya kebutuhan asuransi kesehatan pada golongan umur lansia didominasi oleh pembiayaan katastropik penyakit degeneratif. Penelitian lain mengindikasikan adanya Adverse selection dan penunggakan premi BPJS pada kelompok umur lansia berkaitan dengan faktor produktivitas kinerja dan kesinambungan pendapatan (Intiasari dkk,2015). Penunggakan pembayaran premi mengakibatkan tidak lancarnya pembayarn klaim layanan kesehatan Kebijakan pencegahan adverse selection yang diterapkan saat ini cenderung menimbulkan trade off negatif berupa tidak terlayaninya kebutuhan pembiayaan kesehatan sesuai dengan kebutuhan masyarakat. Komposisi kebutuhan pelayanan kesehatan sesuai kelompok umur pada sektor masyarakat informal harus dimodifikasi secara sistematis untuk revenue collection yang optimal.

Siapa yang harus membayar premi masyarakat sektor informal yang telah lanjut usia? Kebijakan pencegahan adverse selection memerlukan modifikasi terstruktur 
yang dapat mengaktifasi semua tombol fungsi pembiayaan kesehatan. Salah satu rekomendasi yang bisa dilakukan adalah dengan memperbesar cakupan kepesertaan PBI. Negara harusnya mengambil peran untuk menanggung pembayaran premi BPJS untuk masyarakat sektor informal yang tidak lagi produktif di masa lanjut usia. Hal ini dilakukan tanpa mengesampingkan potensi pembayaran premi BPJS oleh masyarakat sektor informal ketika mereka masih berada dimasa masa usia produktif Dukungan terhadap kebijakan perluasan revenue collection yang berkesinambungan dapat dilakukan. Yaitu dengan strategi switching pembayaan premi pada masyarakat sektor informal.

Strategi Switcing Premi : Aktivasi fungsi pembiayaan Kesehatan Strategi switching premi adalah sistem peralihan penanggungjawab pembayar premi BPJS dari masyarakat sektor informal oleh pemerintah. Prinsipnya adalah pengalihan tanggung jawab pembayaran premi oleh pemerintah. Fasilitas switching premi dilakukan dengan berbagai persyaratan guna mendorong masyarakat untuk sektor informal untuk mendaftar sebagai peserta BPJS Non PBI Mandiri.

Mekanisme switching premi dilakukan sesuai syarat ketentuan yang berlaku kemudian. Beberapa yang harus diperhatikan adalah : Fasilitas switching premi diberikan kepada masyarakat sektor informal yang telah menjadi peserta Non PBI

Mandiri selama periode tertentu yang nantinya ditetapkan. Misalnya, untuk mendapatkan fasilitas switching premi, peserta telah rutin membayar premi BPJS selama kurun waktu 25 tahun (dengan asumsi mendaftar di usia 30 tahun dan memutuskan untuk tidak bekerja lagi di usia 55 tahun) di usia. Hal ini akan mendorong masyarakat sektor informal yang saat ini belum mendaftar sebagai peserta BPJS untuk segera mendaftar. Selain itu juga akan mendorong masyarakat Non PBI Mandiri yang saat ini menunggak pembayaran preminya untuk menyelesaikan pembayaran preminya. Ketentuan yang berlaku kemudian sangat dipengaruhi oleh konteks politik dan kebijakan fiskal pemerintahan. Masyarakat sektor informal adalah masyarakat dengan jumlah yang sangat besar dan nantinya mereka pasti akan menjadi tidak produktif seperti sedia kala. Upaya untuk membuka potensi kucuran dana lain dalam revenue collection tetaplah menjadi suatu keharusan. Penguatan kebijakan pemanfaatan sin tax dari industri tembakau layak untuk tetap diperjuangkan. 
Komitmen pemerintah dalam penetapan kebutuhan harus dilakukan secara besaran premi, besaran kapitasi FKTP dan proporsional dengan melibatkan semua besaran klaim InaCBG pada JKN sesuai pemangku kebijakan

PRINSIP SWITCHING PREMI

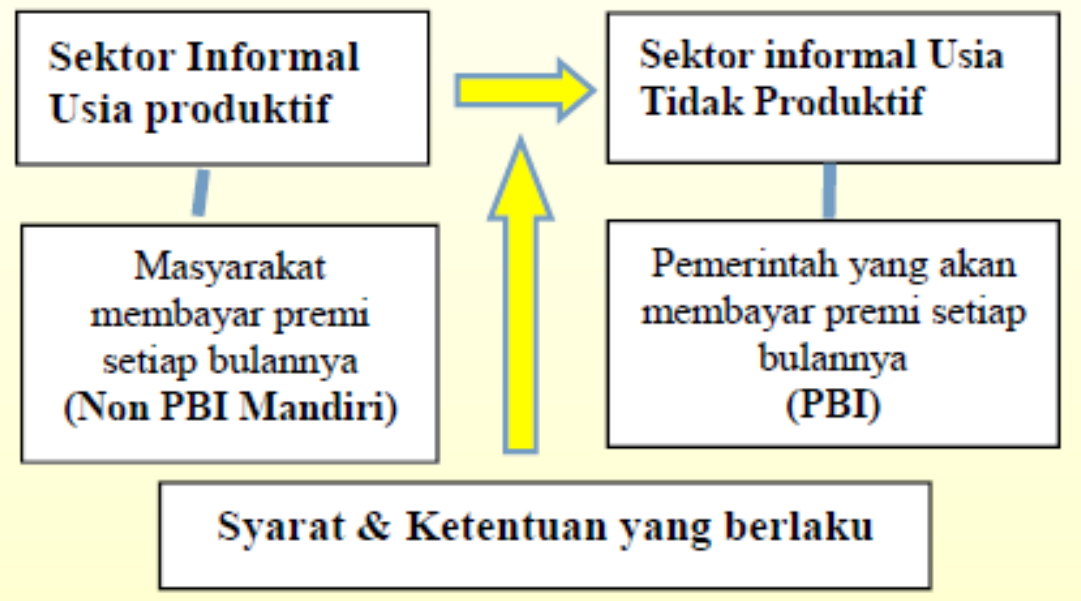

Gambar 2. Prinsip Switching Premi

Sumber : Intiasari,2015

\section{PRINSIP SWITCHING PREMI}

Aktivasi Fungsi Pembiayaan Kesehatan.

Rekomendasi strategi switching premi diharapkan mampu menekan tombol aktivasi fungsi pembiayaan kesehatan pada sistem JKN Besarnya jumlah masyarakat sektor informal adalah peluang dan tantangan tersendiri. Penguatan kebijakan pembiayaan kesehatan pada skema Non PBI Mandiri dapat menjadi kekuatan potensial, terutama bila memang wacana kompartemenisasi skema PBI dan Non PBI akan dilaksanakan. Aktivasi tombol fungsi pembiayaan kesehatan pada strategi switching premi dapat dilakukan sebagai berikut :
Revenue Collection mencakup perluasan cakupan kepesertaan pada sektor informal dapat dilakukan dengan promosi program dan sosialisasi kebijakan yang sistematis. Penekanan unsur manfaat proteksi pada usia lanjut pada strategi switching premi harus terus mendapatkan perhatian.

Risk Pooling, perluasan cakupan kepesertaan pada masyarakat sektor informal dapat memenuhi prinsip law of the large number pada asuransi kesehatan. Kondisi tersebut memungkinkan terjadinya risk pool dengan konsentrasi yang baik, yaitu adanya subsidi dari masyarakat sehat kepada masyarakat yang sakit. Modifikasi 
pada besaran premi kelas 1, 2 dan 3 dapat dilakukan untuk mengakomodasi kebutuhan kesehatan suplemen dan COB dengan asuransi kesehatan komersial pada masyarakat sektor informal dengan status ekonomi yang lebih baik.

Purchasing, Adekuasi pembayaran premi yang berkelanjutan oleh peserta BPJS diperlukan untuk memenuhi kebutuhaan pembayaran klaim biaya pelayanan kesehatan setiap bulannya. Strategi switching premi diharapkan mengeliminir jumlah penunggakan pembayaran premi oleh peserta BPJS Non PBI Mandiri,

Beberapa implikasi yang diharapkan dari rekomendasi strategi switching premi ini antara lain adalah :

1. Strategi switching premi memberikan trade off kebijakan positif. Yaitu terlindunginya masyarakat sektor informal di usia lanjut dari ancaman pembiayaan katastopik akibat gangguan kesehatan degeneratif yang saat ini mengancam.

2. Strategi tersebut diharapkan dapat menumbuhkan konsekuensi perilaku positif pada masyarakat sektor informal yang belum tergerak untuk mendaftar sebagai peserta JKN. Modifikasi promosi dalam peningkatan jumlah kepesertaan dapat dilakukan dengan memberikan jaminan switching pembayaran premi bagi masyarakat sektor informal yang bersedia mendaftar JKN pada usia produktif.

3. Strategi ini diharapkan dapat mengembalikan kepercayaan masyarakat terhadap tujuan kebijakan JKN Yaitu untuk menjamin ketersediaan pelayanan kesehatan bagi seluruh lapisan masyarakat

Persepsi masyarakat terhadap kemungkinan penerapan rekomendasi strategi switching premi adalah sebagai berikut :

1. Sebagai bentuk penghargaan kepada peserta JKN yang telah rutin dan rajin membayar premi tepat waktu

Strategi switching premi mengedepankan konsep pendekatan kebijakan yang mengedepankan pemberian reward kepada masyarakat yang mematuhi sebuah kebijakan. Hal tersebut berbeda dengan kebijakan berbasis punishment berupa denda dan penghentian jaminan pembiayaan kesehatan yang diterapkan oleh BPJS Kesehatan ketika peserta telambtat membayar premi.

"Bagus..memberikan satu apa itu..eee... apa namanya yah.. penghargaan lah, bentuk 
penghargaan kepada masyarakat yang aktif" (informan 8)

Pendekatan kebijakan dalam

teori kepatuhan (Lunenberg,2012) mengidentifikasikan upaya untuk mendekati masyarakat sesuai dengan karakteristiknya. Ada beberapa informan yang masih merasa bahwa pendekatan power koersif dari pemerintah justru memberikan kepastian.

“ Yah...manut sajalah...aturannya bayar premi jangan lebih dari tanggal 10, ya memang seperti aturannya jangan ditawar tawar lagi..kan pasti ada maksudnya biar semua pihak nyaman dan sistemnya teratur" (Informan 2)

Pemberian denda dan penghentian jaminan pelayanan kesehatan masih dinilai efektif pada beberapa komunitas untuk menekan angka keterlambatan pembayaran premi JKN. Akan tetapi sebuah implementasi kebijakan memerlukan modifikasi pendekatan yang bervariasi dalam upaya mencapai kepatuhan sasaran kebijakan.

2. Memberikan rasa kenyamanan akan kepastian jaminan kesehatan di hari tua
Kebutuhan masyarakat sektor informal akan kepastian jaminan kesehatan di hari tua berhadapan dengan kondisi usia non produktif yang nanti akan dijalani. Strategi switching premi memberikan kepastian terhadap kebutuhan jaminan kesehatan di hari tua.

“...ya setuju itu.itu kan meringankan masa tuanya...sudah ada yang njamin kalau butuh biaya ketika sakitsakitan"."(informan 6)

Pada kondisi dimana mereka tidak memungkinkan lagi untuk membayar premi, maka penawaran akan pergantian pembayar premi merupakan suatu kepastian yang melegakan di usia senja.

3. Memberikan semangat untuk membayar premi secara rutin

Kepastian yang diberikan oleh strategi switching premi memicu dan membangkitkan semangat untuk tetap membayar premi secara rutin. Hal tersebut terlandaskan bahwa usia yg masih produktif masih memungkinkan untuk mencari uang yang dibutuhkan untuk membayar premi JKN.

"Yah itu menjadi, mungkin itu akan menjadi daya pancing yah daya pancing untu katif, untuk aktif, eee... 
pembayaran iurannya. Saya kira cukup bagus" (Informan 3)

Harapan dari strategi ini adalah mengaktivasi tombol revenue collection pada masyarakat sektor informal. Aktivasi tombol pertama dari fungsi pembiayaan kesehatan diharapkan dapat memberikan efek yang baik terhadap penurunan defisit anggaran BPJS Kesehatan.

4. Memberikan stimulan kepada masyarakat yang belum mendaftar JKN

JKN memberikan benefit yang komprehensif dengan besaran premi yang relatif murah. Apalagi dibandigkan dengan tingginya besaran asuransi kesehatan swata dengan limitasi manfaat yang beragam. Salah satu penyebabnya adalah prinsip the law of the largae number dalam asuransi. JKN deng besaran premi yang relatif murah membutuhkan target cakupan universal health coverage yang bersifat mutlak.

" Mesti pada ikut mbak kalau tau manfaatnya begitu, karena semua orang bakalannya tua dan sakit yang butuh banyak biaya. Kalau orang yang gajiannya gak tentu kan yang dipikirkan besok kalau sudah gak kerja lagi gimana"
Target enrollment dengan cakupan universal health coverage per Tahun 2019 membutuhkan effort lebih terutama untuk pendekatan kepada masyarakat sektor informal tersebut.

Persepsi negatif terhadap rekomendasi ini juga ditemukan dalam studi ini sebagai berikut :

1. Ketidakpahaman pentingnya kepemilikan jaminan kesehatan di kala sehat

Sehat dan sakit adalah kondisi yang tidak bisa diprediksikan dengan tepat. Salah satu ciri dari ekonomi kesehatan adalah tidak dapat diketahui secara pasti kebutuhan masyarakat akan pelyanan kesehatan yang mereka akan butuhkan. Yang bisa dipastikan adalah bahwa pelayanan kesehatan adalah sebuah kebutuhan yang padat karya dan padat modal. Hal itu menyebabkan harga yang harus dibayar untuk mendapat pelayanan kesehtana tertentu sangatlah mahal.

"Kadang kala juga
masyarakatnya yang terlambat...
apa disengaja atau tidak
disengaja..tapi yang jelas harus
ada penyadaran terhadap
masyarakat betapa pentingnya
asuransi atau jaminan kesehatan


untuk masyarakat khsusnya untuk yang tidak bukan peserta penerima bantuan iuran. Penyadaran yang memang yang masih sulit karena rata-rata mereka itu awalnya kepesertaan itu.. eee... disebabkan karena mentok kepentok artinya harus harus membuat keadaan terpaksa. Kan banyak seperti itu, ini sakit, ini harus segera dibuatkan, akhirnya seolah-olah terpaksa bukan karena penyadaran"(Informan

Perangkat Desa)

Adverse Selection merupakan kondisi yang terjadi ketika pasien "terpaksa" mendaftar asuransi kesehatan karena memang mereka sedang membutuhkan jaminan kesehatan. Adverse selection mempengaruhi keterlambatan pembayaran premi pada JKN.

2. Perceived financial risk yang paling rendah

$$
\text { Masih dijumpai }
$$

ketidakpahaman masyarakat terhadap konsep gotong royong dalam asuransi kesehatan. Masih ada pemahaman dari masyarakat bahwa apabila mereka sakit selama msa membayar premi, maka adalah suatu keuntungan ketika mereka bisa mendapatkan jaminan pembiayaan pelayanan kesehatan. Tetapi apabila mereka tidak pernah mengalami sakit selama masa membayar premi, maka adalah suatu kerugian karena uang terbuang sia-sia. Hal tersebut seperti yang diungkapkan informan berikut ini :

“...itu tergantung, kalo orangnya sering sakit ya termasuk lebih lebih ringan kalau orang nya nggak pernah sakit ya buangbuang uang terus" (Informan 1)

Sosialisasi dengan contoh merupakan hal yang harus secara berkesinambungan dilaksanakan. Mengkomunikasikan semua tujuan kebijakan kepada sasaran memerlukan pendekatan-pendekatan yang berbeda sesuai dengan karakteristik, norma dan budaya masyarakat. Hal ini diungkapkan oleh informan dari Dinkes berikut ini

“ Yang pertama tentunya kesadaran dari masyarakat itu sendiri biar tidak terlambat, membayar iuran kewajibannya setiap bulan, walaupun ada pandangan, saya ndak pernah sakit kok, nah itu yah. Perlu dibuka kesadaran masyarakat" ( Informan Dinkes)

Partisipasi dalam asuransi kesehatan tidak hanya diipengaruhi oleh kemampuan finasial masyarakat semata. Persepsi terhadap konsep asuransi mempengaruhi tingkat kepesertaan jaminan kesehatan di 
suatu negara. Acharya (2013) menemukan bahwa faktor-faktor yang berkontribusi terhadap pendaftaran asuransi kesehatan pada masyarakat sektor informal adalah persepsi,tingkat pendidikan faktor budaya yang berhubungan dengan kesehatan dan perawatan kesehatan, status awal kesehatan, jarak ke fasilitas pelayanan, tekanan kebijakan pemerintah untuk mewajibkan pendaftaran, pemberian insentif pembayaran premi dan proses pelaksanaan administrasi yang buruk.

\section{Ketidakpercayaan} terhadap kemampuan finasial negara dalam mendukung program ini

Kekhawatiram terhadap kemmpuan finasial negara dalam pengganti pembayar premi dalam switching premi adalah reaksi yangwajar muncul dikarenakan ketidak pahaman responde terhadap strategi switching premi secara utuh. Instrumen penelitian tidak menerangkan bahwa subsidi pengganti premi akan dialihkan menjadi penerima bantuan social assistance skema PBI.

“....Tinggal kalau yang seperti itu nanti banyak pemerintah mampu enggak untuk membayar kan itu tinggal dibalikkan pada yang mau membayar ada enggak dananya “

Salah satu syarat yang harus dilakukan oleh strategi switching premi adalah upaya untuk memcari alternatif dana publik secara berkesinambungan untuk memberikan subsidi yang lebih besar bagi masyarakat yang membutuhkan. Beberapa masukan terkait program ini adalah sebagai berikut :

1. Konsep Produktivitas tidak hanya didasarkan pada umur

Hasil riset yang mendasari rekomendasi strategi switching premi hanya melihat variabel umur masyarakat pekerja informal. Penelitian tidak menangkap kemungkinan pekerja pada masyarakat sektor informal akan megalami disabilitas secara ekonomi yang diakibatkan oleh kecelakaan dengan cacat tetap dan atau sakit yang tidak memungkinkan nya dapat bekerja lagi di usia produktif.

“ Kalau memang kedepan ada program seperti itu, kalau yang ada pembedaan antara masyarakat yang produktif karena usia masih memungkinkan dan warga yang tidak produktif karena usia atau karena sakit. Yah sakit yang tidak 
memungkinkan untuk beraktivitas itu sangat baik mba." (informan 7)

Pemberian jaminan kesehatan pada pekerja dengan PHK lebih dari 6 bulan dan penyandang cacat masih merupakan pembahasan karena aturan aturan pada implementasi JKN belum sinkron mengatur hal tersebut. Terjadi ambigu tafsir antara perundang-undangan terkait penentuan kriteria golongan fakir miskin dan orang tidak mampu, khususnya pekerjayang mengalami PHK yang setelah 6 bulan tidakbekerja kembali dan orang cacat total tetap (Laksmiarty, 2016)

2. Sosialisasi terhadap setiap program harus dikedepankan

Sosialisai merupakan upaya untuk mengkomunikasikan pesan kebijakan kepada para stakeholder, baik stakeholder pelaksana maupun stakeholder sasaran. Sosialisasi yang adekuat dan berkelanjutan perlu melibatkan semua sektor dengan sumber daya yang dimilikinya.

"Kendalane sosialisasinya. Kadang masyarakat percaya tapi kan setelah tau. Tapi kadang-kadang kan karena nggak diberi tahu. Sosialisasine kurang. Kalauada sosialisasi, kalau menurut saya kalau buat kesehatan itu ya itu jangan berfikir untung rugi, saya pikir kan kalau kita butuh kan."

$$
\text { Pemahaman yang baik }
$$
terhadap sebuah kebijakan akan menciptakan suasana kondusif untuk saling mendukung upaya implementasi kebijakan JKN, meminimalisir kerugian dan memaksimalkan manfaat yang merupakan tujuan bersama dari JKN.

\section{KESIMPULAN DAN SARAN \\ SIMPULAN}

Adanya dukungan positif dari masyarakat terhadap konsep switching premi dalam JKN. Strategi ini dianggap dapat mengatasi keterlambatan pembayaran premi dan sekaligus memberikan stimulasi untuk meningkatkan cakupan enrollpent kepesertaan JKN

\section{SARAN}

Perlu dilakukan sosialisasi yang adekuat dan berkesinambungan demi terlaksananya implementasi JKN yang lebih baik lagi. Perlu dilakukan kajian untuk menetapkan syarat dan ketentuan yang 
berlaku demi penyempurnaan konsep strategi switching premi.

\section{DAFTAR PUSTAKA}

Acharya A, Vellakal S, Taylor F, Masset E, Satija A, Burke M, Ebrahim S. (2013) The Impact of Health Insurance Scheme for Informal Sector in Low and Middle Income Countries : A Systematic Review. World Bank

Intiasari AD, Masfiah S, Kurniawan A (2014) Model Prediktor Keikutsertaan Masyarakat Sektor Informal Pada Jaminan Kesehatan (Studi Riskesdas 2013 Sebaga Upaya Peningkatan Coverage Peserta Non PBI Mandiri dalam Skema Jaminan Kesehatan Nasional)

Intiasari AD, Aji B, Masfiah S, Trisnantoro L, Hendrartini J (2015) Model Pengumpulan Premi Pada Masyarakat
Sektor Informal di Perdesaan dan Perkotaan Kabupaten Banyumas

Intiasari, AD (2015) Strategi Switching Premi dalam Upaya Pengendalian Adverse Selection Pada Jaminan Kesehatan Nasional : Menjembatani Kebutuhan Pelayanan Kesehatan Masyarakat Sektor Informal. Policy Brief. Disampaikan pada Fornas JKKI V di Padang 25 Oktober 2015.

Laksmiarty, Turniani (2016) Sosialisasi Jaminan Pemeliharaan Kesehatan oleh BPJS KesehatanTerhadap Penduduk Miskin di Indonesia. Policy Brief. Sekretariat Badan Litbangkes Kemkes RI.

Lunenburg FC (2012) Compliance Theory and Organizatioal Effectiveness. International Journal of Scholarly Academic Intellectual Diversity. Volume 14, Number 1, 2012 